Teologia i Moralność, volumen 12(2017), numer 2(22)

doi: 10.14746/tim.2017.22.2.2

\author{
MIECZYSŁAW OZOROWSKI \\ Uniwersytet Kardynała Stefana Wyszyńskiego w Warszawie \\ Wydział Studiów nad Rodziną
}

\title{
Wartość życia ludzkiego w nauczaniu papieży Jana Pawła II, Benedykta XVI i Franciszka
}

W niniejszym opracowaniu podejmiemy próbę prezentacji nauczania ostatnich papieży na temat wartości ludzkiego życia. Przedstawimy tu pewną „ewolucję" poglądów związaną z różną wrażliwością następców św. Piotra. Niewątpliwie wszyscy bronią świętości życia ludzkiego, ale różne są sposoby podejścia do tej problematyki. Niebagatelne znaczenie miała encyklika Evangelium vitae św. Jana Pawła II. Nauczanie to pozostaje niezmienne do dziś.

\section{Nauczanie św. Jana Pawła II o wartości życia}

\section{Pochodzenie życia od Boga}

Istota życia jest misterium nieodgadnionym, tak jak sam Bóg. Jednakże objawienie rzuca nam swoiste światło na to zagadnienie: Bóg jest Życiem. Święty Jan rozpoczyna swój list słowami:

To wam oznajmiamy, co było od początku, cośmy usłyszeli o Słowie życia, co ujrzeliśmy własnymi oczami, na co patrzyliśmy i czego dotykały nasze ręce - bo życie objawiło się. Myśmy je widzieli, o nim świadczymy i głosimy wam życie wieczne, które było w Ojcu, a nam zostało objawione - oznajmiamy wam, cośmy ujrzeli i usłyszeli, abyście mieli współuczestnictwo z nami” (1 J 1,1-3).

Istota życia jest więc odwieczna tak jak sam Bóg i jego boska natura. Jest ona związana $\mathrm{z}$ istnieniem osobowego i żywego Boga. Bóg jest bowiem Bogiem żywych, a nie umarłych. 
Dla ludzi wierzących, Bóg jest nie tylko źródłem wszelkiego istnienia, ale także i wszelkiego życia. Takie życie zaś jest czymś więcej niż tylko zwykłą egzystencją lub prostym faktem istnienia. Życie Boże ma charakter duchowy i jest archetypem każdego bytu. Człowiek wyróżnia się spośród innych istot stworzonych. Chociaż jest ulepiony z tej samej ,gliny”, to został on stworzony na obraz Boży. „Życie, które Bóg daje człowiekowi, jest inne i odrębne od życia wszelkich innych stworzeń żyjących, jako że człowiek, choć jest spokrewniony z prochem ziemi, jest w świecie objawieniem Boga, znakiem Jego obecności, śladem Jego chwały"1.

\section{Dar życia}

Życie ludzkie jest wynikiem stworzenia tak w sensie ogólnym, jak i jednostkowym. Niektórzy współcześni teolodzy (np. Karl Rahner) określają ten proces terminem samoudzielania się Boga. Każde ludzkie życie jawi się jako dar Boga, jako owoc i znak jego miłości². Bóg, stwarzając odrębnie każdego człowieka, obdarowuje go ciałem, psychiką i duszą. Stworzony przez Boga pierwszy człowiek był piękny i dobry. Został on stworzony na obraz i podobieństwo samego Boga (Rdz 1,27). Cały człowiek jest dobry i chciany przez Boga. Darem Bożym jest nie tylko aspekt duchowy człowieka, ale także jego cielesność i to wszystko, co z niej wynika. Prawda ta została potwierdzona i wywyższona przez wcielenie Syna Bożego, który przyjął ludzką naturę wraz z ciałem i duszą. Chrystus nie pogardził ludzką cielesnością, ale zaprezentował jej prawdziwą wartość i sens. Pełne misterium życia ludzkiego da się wyjaśnić tylko przez misterium wcielenia Syna Bożego ${ }^{3}$.

W aspekcie jednostkowym życie ludzkie zawdzięczamy rodzicom. Ludzie przekazują otrzymany od Boga dar z pokolenia na pokolenie przez proces rodzenia. Odbywa się to przy aktywnym współdziałaniu Boga ${ }^{4}$. Jest to jeden z przykładów creatio continua - nieustannego procesu stworzenia. Rodzice przekazują swojemu potomstwu materiał cielesny, a Bóg Stworzyciel, każdorazowo stwarza i daje poczętemu człowiekowi jego duszę. Życie ludzkie jawi się jako podwójny dar. $Z$ jednej strony jako dar rodziców - owoc miło-

${ }^{1}$ Jan Paweł II, Encyklika Evangelium vitae, nr 34 [dalej w tekście EV], https://opoka.org.pl/ biblioteka/W/WP/jan_pawel_ii/encykliki/evangelium_1.html [dostęp: 30.06.2017].

${ }^{2}$ Tamże, nr 81.

3 Kongregacja Nauki Wiary, Instrukcja Dignitas personae dotycząca niektórych problemów bioetycznych, 12 grudnia 2008, $\mathrm{nr} 7 \mathrm{https}$ ://opoka.org.pl/biblioteka/W/WR/ kongregacje/kdwiary/dignitas_personae_12122008.html [dostęp: 30.06.2017].

${ }^{4}$ Paweł VI, Encyklika Humanae vitae (25 lipca 1968), n. 8, „Acta Apostolicae Sedis” 60 (1968), s. $485-486$. 
snego zjednoczenia ojca i matki, a z drugiej strony jako Boży dar ożywiającej duszy. „Bóg, który jest miłością i życiem, wpisał w człowieczeństwo mężczyzny i kobiety powołanie do specjalnego uczestnictwa w swojej tajemnicy osobowej komunii, w dziele Stwórcy i Ojca"5. Życie ludzkie nie należy do nikogo z ludzi: ani do nas samych, ani do rodziców, ani do lekarzy, tylko do samego Boga ${ }^{6}$. Z tego faktu płynie moralny obowiązek, aby z wielkim szacunkiem i troską odnosić się do tego daru. Jan Paweł II wskazuje, że należy troszczyć się i dbać o ten dar, aby życie ludzkie mogło osiągnąć pełny i jak najdoskonalszy rozkwit. Nie dopuszczalne jest ograniczanie i pozbawianie życia jakiekolwiek istoty ludzkiej, od jej początku, od naturalnego poczęcia aż do jej końca, do naturalnej śmierci. Jest to prawo naturalne, pierwotne, które przysługuje każdemu człowiekowi ${ }^{7}$. Oczywiście od każdej zasady są wyjątki, nawet w teologii: np. kara śmierci, sprawiedliwa wojna, obrona konieczna, które obecnie coraz częściej również są kwestionowane. Szacunek do życia jako daru wymaga, aby nauka i technika służyły integralnemu rozwojowi człowieka ${ }^{8}$.

Porządek stworzenia jest uzupełniony przez porządek zbawienia, gdzie życie jako dar odnajduje ubogacenie. Bóg stworzył świat dla człowieka, a człowieka dla samego siebie. Przez grzech pierworodny ludzkość zerwała więź jedności ze Stwórcą. Dopiero Chrystus jako jedyny Zbawiciel przywraca wszystkim ludziom możliwość pojednania się z Bogiem. Odwieczny zamysł Boga Ojca polega na tym, „by [ludzie] się stali na wzór obrazu Jego Syna” (Rz 8,29) ${ }^{9}$. Śmierć Chrystusa na Krzyżu jest jednocześnie darem dla nas i źródłem życia. Na Krzyżu i u jego stóp rodzi się „lud życia”"10. Każdy z wierzą-

\footnotetext{
${ }^{5}$ Kongregacja Nauki Wiary, Instrukcja Donum vitae, Wstęp, 3: „Acta Apostolicae Sedis” 80 (1988), s. 75.

${ }^{6}$ Kongregacja Nauki Wiary, Instrukcja Donum vitae, II, B, 7 „Acta Apostolicae Sedis” 80 (1988), s. 96; por. Pius XII, Przemówienie do uczestników IV Międzynarodowego Kongresu Lekarzy Katolickich (29 września 1949): „Acta Apostolicae Sedis” 41 (1949), s. 560.

${ }^{7}$ Przypominał o tym również papież Benedykt XVI, iż prawa człowieka, w szczególności prawo każdej istoty ludzkiej do życia, «mają swój fundament w prawie naturalnym, zapisanym w sercu człowieka i obecnym w różnych kulturach i cywilizacjach. Oderwanie praw człowieka od tego kontekstu oznaczałoby zawężenie ich zasięgu i ustępstwo wobec koncepcji relatywistycznej, według której znaczenie i interpretacja praw mogłyby ulegać zmianom, a ich uniwersalność można by negować w imię różnych koncepcji kulturowych, politycznych, społecznych czy nawet religijnych. Wielka różnorodność punktów widzenia nie może być wystarczającym powodem, by zapominać, że uniwersalne są nie tylko prawa, lecz także osoba ludzka, która jest podmiotem tych praw» (Przemówienie do Zgromadzenia Ogólnego Organizacji Narodów Zjednoczonych, 18 kwietnia 2008: „Acta Apostolicae Sedis” 100 [2008], 334, „L'Osservatore Romano”, wyd. pol., 5 [2008], s. 57).

${ }^{8}$ Jan Paweł II, Evangelium vitae, $\mathrm{nr} 81$.

9 Jan Paweł II, Veritatis splendor, n. 45: „Acta Apostolicae Sedis” 85 (1993), s. 1169.

${ }^{10}$ Jan Paweł II, Evangelium vitae, nr 51.
} 
cych jest wezwany, ,aby oddać swoje życie za braci, urzeczywistniając w ten sposób prawdziwy sens i przeznaczenie naszej egzystencji”" ${ }^{\prime 1}$.

\section{Godność życia}

Godność ludzkiego życia wynika bezpośrednio z faktu, że jest on stworzony na obraz i podobieństwo Boga (Rdz 1,27). Życie ludzkie jest godne, ponieważ człowiek jest osobą, jest zdolny do poznawania siebie, do panowania nad sobą, do tworzenia wspólnoty z innymi osobami, a przede wszystkim jest powołany do wspólnoty z Bogiem (KKK 356$)^{12}$. Godność osoby ma charakter trwały, niezbywalny i zobowiązujący ${ }^{13}$. Godność ta w człowieku jest stała i nieredukowalna, niezależna od jego wieku, stanu zdrowotnego, psychicznego czy duchowego. Oczywiście taką samą godnością Bóg obdarzył mężczyznę i kobietę (KKK 369). Jednocześnie jest ona źródłem, kryterium i kresem odniesienia każdej wartości moralnej ${ }^{14}$.

Papież Jan Paweł II wielokrotnie przypominał, że godność ludzkiego życia polega na tym, że jest ono szczególną własnością Boga ${ }^{15}$. Godność rodziców płynie stąd, że są oni współpracownikami Boga w dziele stworzenia $(\text { KKK } 372)^{16}$. „Miłość małżeńska i rodzicielska jest znakiem urzeczywistnienia miłości Boga"17.

Życie ludzkie różni się od egzystencji wszelkich innych stworzeń żyjących. Choć człowiek jest podobny do innych stworzeń ziemskich i spokrewniony $\mathrm{z}$ nimi, jest on $\mathrm{w}$ świecie objawieniem Boga, znakiem Jego obecności i śladem Jego chwały (Ps 103,14; 104,29). Człowiek góruje nad światem zwierząt swoją godnością osoby i podobieństwem do Boga. Stworzyciel daje polecenie pierwszym ludziom: „rozmnażajcie się, abyście zaludnili ziemię i uczynili ją sobie poddaną; abyście panowali [...] nad wszystkimi zwierzętami” (Rdz 1,28).

${ }^{11}$ Tamże.

${ }^{12}$ KKK - Katechizm Kościoła katolickiego, tekst polski, Poznań 1994.

${ }^{13}$ E. Ozorowski, Dar życia w porzadku stworzenia i zbawienia w świetle „Evangelium vitae”, w: Evangelium vitae - ocaleniem rodziny, red. M. Ozorowski, Częstochowa 1997, s. 61-63.

${ }^{14}$ Por. E. Podrez, Człowiek, byt, wartość, Warszawa 1989 s. 103-125.

${ }^{15}$ Jan Paweł II, Evangelium vitae, $\mathrm{nr} 34$.

16 „Poszanowanie tej godności należy się każdej istocie ludzkiej, gdyż są w niej zapisane w sposób niezatarty właściwa jej godność i wartość. Z drugiej strony, początek życia człowieka ma swój prawdziwy kontekst $w$ matżeństwie $i w$ rodzinie, w której zostaje ono poczęte poprzez akt wyrażający wzajemną miłość mężczyzny i kobiety. Prokreacja prawdziwie odpowiedzialna wobec mającego się narodzić dziecka winna «być owocem małżeństwa» - Kongregacja Nauki Wiary, Instrukcja Dignitas personae dotycząca niektórych problemów bioetycznych, 12 grudnia 2008, nr 6 .

${ }^{17}$ E. Ozorowski, Dar życia w porzadku stworzenia i zbawienia..., s. 63. 
Ta wzniosła godność człowieka została przyćmiona przez grzech pierworodny (Rdz 3,1-7). Wprowadził on dysharmonię w egzystencję człowieka. Obraz Boży został oszpecony, a człowiek doznaje pokusy, aby go zniekształcać także u innych, wprowadzając w miejsce wzajemnej komunii nieufność, obojętność i wrogość, posuwając się nawet do zabójczej nienawiści - w ten sposób Kain ciągle nastaje na życie sprawiedliwego Abla ${ }^{18}$. Grzech jednak nie zniszczył w człowieku jego godności. Godność człowieka ponownie zajaśniała Bożym blaskiem wraz z przyjściem Zbawiciela. Tylko w Chrystusie ludzie mogą odnaleźć własną tożsamość dziecka Bożego oraz odzyskać pełnię życia ${ }^{19}$.

Godność ludzkiego życia wskazuje także na cel, jakim jest życie wieczne w Bogu, komunia z Bogiem, poznawanie i miłowanie $\mathrm{Go}^{20}$. Święty Ireneusz pozostawił powiedzenie: „Albowiem chwałą Boga jest żyjący człowiek, a życiem człowieka jest oglądanie Boga"21. Życie, które prowadzimy na Ziemi, jest początkiem życia w wiecznym szczęściu i światłości niebieskiej. Mamy niewzruszoną nadzieję na pełnię uczestnictwa w życiu wiekuistego Boga ${ }^{22}$. Życie ziemskie jest tylko przedsmakiem dóbr, które przygotował nam Bóg w zmartwychwstałym ciele.

Człowiek stanowi jedność duchowo-cielesną. Cały człowiek jest dobry i chciany przez Boga (KKK 362-365). Ludzie nie powinni pogardzać swoimi ciałami, lecz powinni odnosić się do nich z szacunkiem, ponieważ zostały przez Boga stworzone i po zmartwychwstaniu będą uczestniczyć w chwale dzieci Bożych (KDK 14) ${ }^{23}$. Ciało ludzkie uczestniczy w godności osobowej człowieka, jest znakiem i miejscem relacji z innymi, z Bogiem i światem ${ }^{24}$.

Ze względu na tę osobową godność każdemu życiu ludzkiemu należy się szacunek, bezinteresowność i służba. Jeżeli tego zabraknie, jego wartość określa się, uwzględniając jego wydajność, funkcjonalność i przydatność. Cenione jest nie za to, kim jest człowiek, ale za to, co posiada. Życie ludzkie jest wówczas zagrożone, ponieważ jest traktowane jako produkt i towar ${ }^{25}$.

\section{Ostrzeżenie przed zagrożeniem życia oraz apel o kulturę życia}

Życie ludzkie od samego początku stworzenia narażone było na liczne zagrożenia. Szatan, kusiciel człowieka był i jest nadal wrogiem życia

\footnotetext{
${ }^{18}$ Jan Paweł II, Evangelium vitae, nr 36.

19 Tamże.

${ }^{20}$ Jan Paweł II, Evangelium vitae, $\mathrm{nr} 38$.

${ }^{21}$ Ireneusz, Adversus haereses, 4,20, 7; Sch 100/2, s. 648-649.

${ }^{22}$ Jan Paweł II, Evangelium vitae, nr 37.

${ }^{23} \mathrm{KDK}$ - Sobór Watykański II, Konstytucja duszpasterska o Kościele, Gaudium et spes.

${ }^{24}$ Jan Paweł II, Evangelium vitae, nr 23.

25 Tamże.
} 
(Rdz 3,1-24). Od momentu wygnania z Raju człowiek skłania się do działania według „logiki Złego” (J 8,44). Święty Jan Paweł II w Evangelium vitae (nr 7-24) rozwijał opis zagrożeń, wychodząc od opowiadania o zbrodni Kaina na Ablu (Rdz 4,1-16). Papież dostrzegał wiele zagrożeń ludzkiego życia. Wiek XX ocenił jako epokę masowych ataków na życie ludzkie, jako niekończącą się serię wojen i nieustanną masakrę niewinnych istot ludzkich. Pisał on wręcz o obiektywnym ,spisku przeciw życiu”, zaaranżowanym przez instytucje międzynarodowe i rządy wielu państw ${ }^{26}$.

Święty Jana Paweł II wskazywał na dwa momenty, w których życie ludzkie jest najbardziej wrażliwe i wymaga szczególnej ochrony: początek życia i jego koniec. Do zagrożeń związanych z początkową fazą ludzkiego życia Ojciec św. zaliczał: antykoncepcję, aborcję ${ }^{27}$, techniki sztucznej reprodukcji (zapłodnienie in vitro) ${ }^{28}$, eksperymenty dokonywane na embrionach, wykorzystywanie embrionów ludzkich jako źródła organów albo tkanek do przeszczepów ${ }^{29}$. Instrukcja Dignitas personae dotycząca niektórych problemów bioetycznych, wydana przez Kongregację Nauki Wiary w 2008 roku podaje jeszcze dłuższą listę zagrożeń wraz z uzasadnieniem etycznym i moralnym.

Koniec życia ludzkiego zagrożony jest przede wszystkim przez eutanazję ${ }^{30}$. Kościół nigdy nie godził się na zabijanie ludzi, samobójstwo (wspomagane $)^{31}$. Oczywiście dopuszczalna jest rezygnacja z nadzwyczajnych i przesadnych zabiegów, które powodowałyby jedynie uciążliwe przedłużenie życia.

${ }^{26}$ Jan Paweł II, Evangelium vitae, nr 17. Przytoczmy tu krótką, celna i aktualną analizę problemu: „Jakże nie wspomnieć tu o przemocy wymierzonej przeciw życiu milionów istot ludzkich, zwłaszcza dzieci, zmuszonych znosić nędzę, niedożywienie i głód z powodu niesprawiedliwego podziału zasobów ziemi między poszczególne narody i klasy społeczne? O przemocy nieodłącznie związanej nie tylko z wojną, ale także $\mathrm{z}$ gorszącym handlem bronią, która przyczynia się do zaostrzenia licznych konfliktów zbrojnych, nękających świat? O zasiewie śmierci, jaki dokonuje się przez bezmyślne naruszanie równowagi ekologicznej, przez zbrodniczy handel narkotykami i przez propagowanie wzorców zachowań w dziedzinie życia płciowego, które nie tylko są moralnie nie do przyjęcia, ale rodzą także poważne niebezpieczeństwa dla życia? Nie sposób sporządzić pełnej listy różnorakich zagrożeń życia ludzkiego, tak wiele jawnych i ukrytych form przybierają w naszych czasach!" - Jan Paweł II, Evangelium vitae, nr 10.

${ }^{27}$ EV 61: „Życie ludzkie jest święte i nienaruszalne w każdej chwili istnienia, także w fazie początkowej, która poprzedza narodziny. Człowiek już w łonie matki należy do Boga, bo Ten, który wszystko przenika i zna, tworzy go i kształtuje swoimi rękoma, widzi go, gdy jest jeszcze małym, bezkształtnym embrionem, i potrafi w nim dostrzec dorosłego człowieka, którym stanie się on w przyszłości i którego dni są już policzone, a powołanie już zapisane $\mathrm{w}$ «księdze żywota» (por. Ps 139,1.13-16). Jak poświadczają liczne teksty biblijne, także człowiek ukryty jeszcze w łonie matki jest w pełni osobową istotą, ku której zwraca się miłościwa i ojcowska Opatrzność Boga".

${ }^{28}$ Jan Paweł II, Evangelium vitae, nr 13-14, 58-62.

${ }^{29}$ Tamże, nr 63.

${ }^{30}$ Tamże, nr 64.

${ }^{31}$ Tamże, nr 66. 
Kościół akceptuje ludzką kondycję w obliczu śmierci ${ }^{32}$. Należy pamiętać, że każdy człowiek wobec zbliżającej się śmierci ma prawo do wypełnienia swoich obowiązków moralnych i rodzinnych, a zwłaszcza ma prawo do w pełni świadomego przygotowania się na ostateczne spotkanie z Bogiem ${ }^{33}$.

Ojciec św. widział przyczynę tych negatywnych zjawisk w osłabieniu wrażliwości na Boga i człowieka: „tracąc wrażliwość na Boga, traci się także wrażliwość na człowieka, jego godność i życie, z drugiej strony, systematyczne łamanie prawa moralnego, zwłaszcza w poważnej materii poszanowania życia ludzkiego i jego godności, prowadzi stopniowo do swoistego osłabienia zdolności odczuwania ożywczej i zbawczej obecności Boga"34. Bez Boga człowiek ma tendencję do patrzenia na swoje życie jako na jakąś „,rzecz”, którą uważa za swoją wyłączną własność i którą może poddawać wszelkim manipulacjom ${ }^{35}$.

Święty Jan Paweł II we współczesnym świecie zauważał wojnę pomiędzy „kulturą śmierci” i „kulturą życia”. Postrzegał ją jako walkę o przetrwanie naszej cywilizacji. Papież apelował o powszechną mobilizację sumień, „aby wprowadzić w czyn wielką strategię obrony życia. Wszyscy razem musimy budować nową kulturę życia"36. Zwracał się on przede wszystkim do chrześcijan, których nazywał „ludem życia”, mającym głosić Ewangelię życia. Niemniej jednak zwracał się do wszystkich, także do niewierzących, aby podjąć dialog na temat podstawowych problemów ludzkiego życia. Dialog ten mógłby być prowadzony w ośrodkach twórczości intelektualnej, w różnych środowiskach naukowych, lekarskich, ekologicznych, wszędzie tam, gdzie konieczna jest troska o życie ${ }^{37}$. Jan Paweł II nakazywał poszukiwanie racji umacniających i uzasadniających szacunek dla ludzkiego życia ${ }^{38}$. Troska ta powinna obejmować całe życie człowieka, we wszystkich jego wymiarach, i życie wszystkich ludzi ${ }^{39}$.

Pierwszym miejscem rozwoju kultury życia jest rodzina, w której człowiek przychodzi na świat. To tu ludzkie życie rozwija się i dojrzewa. Drugim obszarem jest świat medycyny, który troszczy się o zachwiane zdrowie człowieka, a niekiedy ratuje mu życie. Są też ośrodki specjalnej troski o życie: domy pogodnej starości, hospicja, ośrodki dla upośledzonych oraz inwalidów

${ }^{32}$ Kongregacja Nauki Wiary, Deklaracja o eutanazji Iura et bona (5 maja 1980), „Acta Apostolicae Sedis" 72(1980), s. 546-551.

${ }^{33}$ Jan Paweł II, Evangelium vitae, $\mathrm{nr} 65$.

${ }^{34}$ Tamże, nr 21.

${ }^{35}$ Tamże, nr 22.

${ }^{36}$ Jan Paweł II, Evangelium vitae, nr 95.

${ }^{37}$ Tamże.

${ }^{38}$ Tamże, nr 82.

${ }^{39}$ Tamże, nr 87. 
i szereg podobnych instytucji. Ważnym elementem są ruchy i stowarzyszenia, których celem jest obrona życia. Człowiek ma troszczyć się nie tylko o siebie, ale też o środowisko życia. W tym zakresie ludzie są odpowiedzialni nie tylko przed Bogiem, ale i przyszłymi pokoleniami ${ }^{40}$.

Kościół zachęca do pracy wychowawczej, która pozwala stawać się coraz bardziej człowiekiem, zachować szacunek do życia i nawiązywać prawidłowe relacje międzyosobowe ${ }^{41}$. Wychowanie nie może ograniczać się tylko do dzieci i młodzieży. Pomoc pedagogiczna powinna obejmować także małżonków w zakresie regulacji płodności i życia rodzinnego, osoby upośledzone i niepełnosprawne, toksykomanów itd. ${ }^{42} \mathrm{~W}$ refleksji pedagogicznej należy wziąć pod uwagę zagadnienia cierpienia i śmierci. Ważną rolę odgrywa tu odpowiednio uformowany personel medyczny i odpowiednia organizacja: szpitali, klinik, ośrodków rekonwalescencji, ośrodków opieki paliatywnej.

Święty Jan Paweł II stawiał na rodzinę. Nazywał ją „sanktuarium życia i Kościołem domowym". Podstawowy obowiązek przekazywania życia i opieki nad nim spoczywa na rodzicach. W sposób szczególny zwracał się do, wypełniających macierzyńską misję, kobiet ${ }^{43}$. Rodzicom należy się odpowiednia pomoc ze strony nauczycieli i wychowawców w bezpośrednim wychowaniu nowego pokolenia do życia ${ }^{44}$.

\section{Papież Benedykt XVI o życiu jako pasji}

Papież Benedykt XVI jako wielki teolog do problematyki wartości życia i jego obrony podchodził w inny sposób niż jego poprzednik. Zauważalna jest tu jego wielka pokora i skromność. Następca Jana Pawła II również stawiał w centrum swego przepowiadania wartość ludzkiego życia i widział je w głębokiej perspektywie odniesienia do Boga, zbawienia i życia wiecznego. Swoją naukę przekazywał spokojnie bez emocjonalnego nacechowania, dzięki któ-

40 Tamże, $\mathrm{nr} 42$.

${ }^{41}$ Tamże, nr 97.

42 Tamże, nr 88, 97.

${ }^{43}$ Tamże, nr 99.

44 „Wielka i poważna odpowiedzialność spoczywa na pracownikach środków przekazu: mają oni troszczyć się o to, aby treści przekazywane w sposób tak skuteczny służyły kulturze życia. Winni zatem ukazywać wzniosłe i szlachetne przykłady życia i poświęcać uwagę pozytywnym, a czasem wręcz heroicznym świadectwom ludzkiej miłości; z wielkim szacunkiem mówić o wartościach płciowości i miłości, nie akcentując tego, co oszpeca i poniża ludzką godność. Interpretując rzeczywistość, powinni unikać podkreślania tego, co może budzić lub podsycać uczucia czy postawy obojętności i pogardy wobec życia lub skłaniać do odrzucenia go. Przestrzegając skrupulatnie zasady wierności prawdzie, mają łączyć w jedną całość wolność informacji, szacunek dla każdej osoby i głęboki zmysł człowieczeństwa" - Jan Paweł II, Evangelium vitae, nr 98. 
remu słuchacze łatwiej by je zauważyli. Należy ze spokojem studiować dokumenty Benedykta XVI, a także wcześniejsze teksty Józefa Ratzingera, aby znaleźć prawdę o życiu ludzkim i o jego nienaruszalności ${ }^{45}$.

Papież Benedykt XVI ma teologiczną wizję człowieka jako „świętej” istoty stworzonej przez Boga na Jego obraz i podobieństwo ( $\mathrm{Rdz} 1,26)$. Ma ona niezbywalną godność osobową i jest podstawą braterstwa wszystkich ludzi. Swój sens istnienia znajduje on tylko w Bogu ${ }^{46}$. Jeszcze jako prefekt Kongregacji Nauki Wiary przypominał za św. Janem Pawłem II, że przykazanie „nie zabijaj” ma charakter powszechny i ponadhistoryczny. Świadomość poszanowania ludzkiego życia jest obecna we wszystkich społecznościach ${ }^{47}$. Chrześcijanie od początku odróżniali się od pogan wielkim szacunkiem do ludzkiego życia ${ }^{48}$.

Benedykt XVI, podobnie jak jego poprzednicy, stawał w obronie życia i ostrzegał przed licznymi zagrożeniami, zwłaszcza przed plagą aborcji $(\mathrm{CiV} 28)^{49}$. Papież uważał się wręcz za rzecznika istot, które mają się narodzić, a nie mają głosu ${ }^{50}$. Twierdził on, że „w naszej społeczności dokonuje się zagłady życia: obok ofiar konfliktów zbrojnych, terroryzmu i różnorakich form przemocy są ofiary cichej śmierci, spowodowanej przez głód, przez aborcję, eksperymenty na embrionach i eutanazję"51. Sprzeciwiał się wyraźnie manipulacjom eugenicznym na ludzkich embrionach ${ }^{52}$. Papież Benedykt XVI wielokrotnie apelował do różnych środowisk o aktywne zaangażowanie się w obronę ludzkiego życia. Apel swój kierował do rodziców, kapłanów, a przede wszystkim środowiska medycznego ${ }^{53}$.

${ }^{45}$ D. Cieślik, Nienaruszalność życia ludzkiego w nauczaniu Benedykta XVI, „Studia Teologiczno-Historyczne Śląska Opolskiego" (2015) 35, s. 210.

46 J. Ratzinger, Człowiek - reprodukcja czy stworzenie? Teologiczne pytania dotyczace początków życia ludzkiego, „Ethos” 1 (1988) 4, s. 141.

47 J. Ratzinger, Nienaruszalność życia ludzkiego w świetle encykliki „Evangelium vitae”, „L'Osservatore Romano” wyd. pol. 16 (1995) 5, s. 48.

48 J. Ratzinger, Życie - fundamentalna wartościa i nienaruszalnym prawem człowieka, „Ethos” 2 (1987) 5, s. 23.

${ }^{49}$ Benedykt XVI, Gdy człowiek postępuje wbrew sumieniu, rani samego siebie, „L'Osservatore Romano" wyd. pol. 32 (2011) 4, s. 14.

${ }^{50}$ Benedykt XVI, Wiedeń. Spotkanie ze światem polityki, 7.IX.2007, „L'Osservatore Romano” wyd. pol. 28 (2007), s. 10-11.

${ }^{51}$ Benedykt XVI, Orędzie Ojca Świętego Benedykta XVI na Światowy Dzień Pokoju, 1.I.2007, p. 5. http://www.opoka.org.pl/biblioteka/W/WP/benedykt_xvi/przemowienia/pokoj2007_08122006. html [dostęp: 30.06.2017].

52 J. Ratzinger, Problem zagrożeń życia ludzkiego, „L'Osservatore Romano” wyd. pol. 12 (1995) 7, s. 4; Benedykt XVI, Człowiek to coś więcej niż kombinacja informacji genetycznych, „L'Osservatore Romano" wyd. pol. 30 (2009) 4, s. 32.

${ }^{53}$ Benedykt XVI, Życie jest pierwszym dobrem, jakie otrzymujemy od Boga, i podstawa wszystkich innych, „L'Osservatore Romano” wyd. pol. 28 (2007), nr 5, s. 45. 
Zwracał się również do polityków, aby ustanawiali prawo chroniące człowieka od poczęcia do naturalnej śmierci ${ }^{54}$. Poszanowanie życia jest pierwszym warunkiem sprawiedliwości społecznej, ponieważ jest prawem fundamentalnym. Prosił również naukowców zajmujących się różnymi dyscyplinami wiedzy, aby kierowali się dobrem człowieka i sprzeciwiali się redukcjonistycznej wizji istoty ludzkiej ${ }^{55}$. Współczesność charakteryzuje się walką przeciw życiu. Według papieża Benedykta ludzie wierzący powinni się mobilizować, by bronić każdego człowieka, a szczególnie takiego, który jest bezbronny i znajduje się $\mathrm{w}$ potrzebie $\mathrm{z}$ powodu starości, choroby czy biedy ${ }^{56}$. Współczesna kultura charakteryzuje się zanikiem poczucia sensu życia i skłania się ku „kulturze śmierci”, gdzie łatwo akceptuje się aborcję oraz inne zamachy na bezbronne życie, wierząc, że rozwiążą one problemy rodzinne i społeczne ${ }^{57}$. Bóg w swojej miłości nie robi różnicy pomiędzy dziećmi ledwo co poczętymi, młodzieżą, ludźmi dojrzałymi i starcami. Wszystkich jednakowo kocha i ceni. Strata każdego życia jest stratą dla całej ludzkości ${ }^{58}$. Papież Benedykt przypominał, że Kościół głosi zasady, które nie podlegają żadnym negocjacjom: należy bronić życia we wszystkich jego fazach od chwili poczęcia aż po jego kres w naturalnej śmierci.

Papież Benedykt XVI umieszczał problematykę obrony życia w szerszym kontekście: rozwoju ludzkości, obrony pokoju światowego, ostatecznego celu ludzkiego życia. Tak tę sprawę przedstawił w encyklice Caritas in veritae (28):

Jednym z najbardziej oczywistych aspektów dzisiejszego rozwoju jest doniosłość zagadnienia szacunku dla życia, którego w żadnej mierze nie można oddzielać od spraw związanych z rozwojem narodów. [...] Otwarcie się na życie jest ośrodkiem prawdziwego rozwoju. Kiedy jakieś społeczeństwo skłania się ku negowaniu i unicestwianiu życia, nie znajduje już motywacji i energii potrzebnych do angażowania się w służbę prawdziwego dobra człowieka. Jeśli dochodzi do utraty

${ }^{54}$ Benedykt XVI, Serce rozumne. Refleksje na temat podstaw prawa, „L'Osservatore Romano” wyd. pol. 32 (2011) 4, s. 39.

55 Benedykt XVI, Ludzka i chrześcijańska godność prokreacji, „L'Osservatore Romano” wyd. pol. 33 (2012), nr 4, s. 39; Benedykt XVI, Człowiek to coś więcej niż kombinacja informacji genetycznych, „L'Osservatore Romano” wyd. pol. 30 (2009), nr 4, s. 31.

${ }_{56}$ Benedykt XVI, Przestanie do uczestników 25. Międzynarodowej Konferencji Papieskiej Rady ds. Stużby Zdrowia i Duszpasterstwa Chorych, „L'Osservatore Romano” wyd. pol. 32 (2011), $\mathrm{nr}$ 1, s. 25; Benedykt XVI, Życie ma wielka wartość, nawet kiedy jego piękno przysłania tajemnica cierpienia.Orędzie Ojca Świętego na XVII Światowy Dzień Chorego, „L'Osservatore Romano” wyd. pol. 30 (2009), nr 3, s. 8.

${ }^{57}$ A. Grześkowiak, Wybrane aspekty nauczania Benedykta XVI o rodzinie, w: Człowiek z perspektywy religii, rodziny i szkoły, red. H. Czakowska, M. Kucinski, Bydgoszcz 2013 s. 162.

${ }^{58}$ Benedykt XVI, Spotkanie z czlonkami rzadu, instytucji państwowych, korpusu dyplomatycznego, zwierzchnikami religijnymi i przedstawicielami świata kultury, 15.IX.2012, „L'Osservatore Romano" wyd. pol. 33 (2012), s. 9-10. 
wrażliwości osobistej i społecznej na przyjęcie nowego życia, również inne formy otwarcia przydatne dla życia społecznego ulegają wyjałowieniu.

Jest jeszcze jeden wymiar nauki papieża Benedykta XVI na temat ludzkiego życia. Osobiście traktował on życie jako pasję w jej teologicznym znaczeniu. Opisuje to zagadnienie obszernie Ksiądz profesror Jerzy Szymik w swoim dziele Theologia benedicta ${ }^{59}$. Życie jako pasja to cierpienie i silne zamiłowanie, to również męka Jezusa oraz jej ewangeliczny opis. Życie człowieka można zrozumieć tylko w świetle ofiary pasyjnej Jezusa Chrystusa Syna Bożego i Syna Człowieczego. Dzięki misteriom Chrystusowym możemy przeżywać pasję Jezusową, a On przeżywa pasję człowieczeństwa ${ }^{60}$. Siłą chrześcijańskiego życia jest moc miłości gotowej ponieść cierpienie i ofiarę ${ }^{61}$. Pasja życia to: miłość i cierpienie, nuda wygasłej wegetacji oraz ogień i żar istnienia, a także światło prawdziwej pobożności i wiary ${ }^{62}$. Ujęcie papieskie jest głęboko egzystencjalne i osobiste, a także naznaczone poetyką teologiczną. Ludzka (chrześcijańska ) pasja życia jest zakorzeniona w wierności pasji Chrystusa. Są takie wartości jak: życie, wiara i miłość, dla których warto cierpieć, a nawet oddać swoje życie. Takie jest świadectwo męczenników: Życie jest warte życia, ponieważ jest warte śmierci, a my jesteśmy dziećmi jedynego Króla oraz potrafimy rozpoznać prawdę i stawiamy ją ponad wszelką przemoc ${ }^{63}$. Życie wiąże się z cierpieniem, trudem i ofiarą, na wzór Chrystusa, który wziął swój Krzyż, zaniósł go na Golgotę i umarł dla naszego zbawienia. Jednakże życie to nie tylko królewska droga martyrologii, ale także pasja w prostym znaczeniu. Kardynał Józef Ratzinger, później jako Benedykt XVI, w prostocie swego życia miał również swoje pasje: muzykę, literaturę, a przede wszystkim teologię, a czasem, jak mówią świadkowie, mały papieros ${ }^{64}$.

Niemniej jednak życie chrześcijanina (ars vitae christianae) to życie w posłuszeństwie samemu Bogu, to życie dla innych to proegzystencja na wzór Chrystusa ${ }^{65}$. Ostateczną racją i sensem ludzkiego życia jest Bóg i Jego niezgłębiona miłość ${ }^{66}$. Jako podsumowanie nauczania papieża Benedykta XVI zacytuję zdanie z jego książki: „Miłość jest możliwa i możemy ją realizować,

${ }^{59}$ J. Szymik, Theologia benedicta, t. 3, Katowice 2015, s. 249-268.

${ }^{60}$ J. Ratzinger, Wiara i przyszłość, Kraków 2007 s. 62.

${ }^{61}$ J. Ratzinger, Kościól - Ekumenizm - Polityka, Poznań-Warszawa 1990 s. 45.

62 J. Szymik, Theologia benedicta, s. 355.

${ }^{63} \mathrm{~J}$. Ratzinger, Prawda, wartości, władza. Kiedy spoleczeństwo można uznać za pluralistyczne, Kraków 1999 s. 45.

${ }^{64}$ G. Ratzinger, Mój brat Papież, Kraków 2012 s. 130, 171, 243.

${ }^{65}$ J. Ratzinger, Formalne zasady chrześcijaństwa. Szkice do teologii fundamentalnej, Poznań 2009 s. 256; J. Szymik, Theologia benedicta, s. 363-366.

${ }^{66}$ Benedykt XVI do osób konsekrowanych, red. M. Saj, Kraków 2009 s. 172. 
bo jesteśmy stworzeni na obraz Boga. Żyć miłością i w ten sposób sprawić, aby Boże światło dotarło do świata - do tego właśnie chciałbym zachęcić" ${ }^{67}$.

\section{Papież Franciszek o celebrowaniu życia}

Papież Franciszek w zakresie nauczania o wartości i obronie życia ludzkiego wpisuje się w linię wyznaczoną przez swoich wielkich poprzedników. Nie modyfikuje on doktryny, ale stara się ukazać jej nowy duszpasterski wymiar. Przemawiając do lekarzy katolickich, zachęcał, aby pamiętali, że życie ludzkie jest zawsze, na każdym etapie, święte i zawsze ma wielką wartość, i to nie tylko ze względu na wiarę, ale także $z$ uwagi na rozum i naukę ${ }^{68}$. Każde życie ludzkie ma jednakową wartość - dodał Ojciec św. Prostym, duszpasterskim językiem przypominał on o wartości życia, które musi być chronione:

Żyjemy w czasach eksperymentów na życiu. Lecz złych eksperymentów. Produkowania dzieci zamiast przyjmowania ich jako dar, jak powiedziałem. Bawienia się życiem. Uważajcie, bo to jest grzech przeciwko Stwórcy: przeciwko Bogu Stwórcy, który stworzył rzeczy w taki sposób. Wiele razy w moim życiu kapłańskim słyszałem obiekcje. „Ale powiedz mi, dlaczego Kościół sprzeciwia się aborcji, na przykład? Czy to jest problem religijny”? - „Nie, nie. To nie jest problem religijny”. - „Czy to jest problem filozoficzny?” - „Nie, nie jest to problem filozoficzny". To jest problem naukowy, ponieważ tam jest życie ludzkie, i nie jest dozwolone zabijanie ludzkiego życia, by rozwiązać problem. „Ależ nie, nowoczesna myśl...” - „Słuchaj, w myśli starożytnej i w myśli nowoczesnej słowo zabić znaczy to samo!". I podobnie jest z eutanazją: wszyscy wiemy, że w związku z tym, że jest tyle osób starszych, w tej kulturze odrzucania praktykuje się ukrytą eutanazję. Lecz jest też inna. A to znaczy powiedzieć Bogu: „Nie, koniec życia wyznaczam ja, tak jak chcę”. Grzech przeciwko Bogu Stworzycielowi. Zastanówcie się nad tym dobrze ${ }^{69}$.

Podobnie jak poprzednicy, niejednokrotnie zwraca się on z apelem o obronę ludzkiego życia od poczęcia po jego kres tu, na Ziemi. Każde życie jest

${ }^{67}$ Benedykt XVI, Dlaczego wierzę? Przestanie pontyfikatu 2005-2013, Kraków 2013 s. 84.

${ }^{68}$ Papież Franciszek pisał już o tym w adhortacji Evangelii gaudium (213): „Każda istota ludzka - przypomina - jest zawsze święta i nienaruszalna w jakiejkolwiek fazie swego rozwoju. Jest ona celem samym w sobie, a nigdy środkiem do rozwiązania innych trudności. [...] Sam rozum wystarczy, aby uznać nienaruszalną wartość każdego ludzkiego życia, ale jeśli spojrzymy na nie w świetle wiary, wszelki gwałt zadany osobistej godności osoby ludzkiej wzywa o pomstę przed obliczem Bożym i jest obrazą Stwórcy człowieka".

${ }^{69}$ Franciszek, Przemówienie do przedstawicieli Włoskiego Stowarzyszenia Lekarzy Katolickich 15.11.2014, „L'Osservatore Romano” wyd. pol. 35 (2014) 12. http://www.opoka.org.pl/ biblioteka/W/WP/franciszek_i/przemowienia/lekarze_15112014.html [dostęp: 30.06.2017]. 
piękne i święte oraz powinno być podziwiane i bronione ${ }^{70}$. Na łonie rodziny powinien następować przekaz związany z kulturą i obroną życia. Ojciec św. zaznacza, że przekaz podstawowych prawd wiary dotyczących życia i miłości dokonuje się nie tylko słowem, ale przede wszystkim przez przykład własnego życia oraz konkretne czyny. Zwłaszcza wobec kultury odrzucenia, która relatywizuje wartość życia ludzkiego, rodzice są powołani do przekazania swym dzieciom świadomości, że należy go bronić, począwszy od łona matki. Chrześcijanin powinien nauczyć się w nim rozpoznać Boży dar i gwarancję przyszłości dla rodzaju ludzkiego ${ }^{71}$.

Papież Franciszek wzywa także do dawania świadectwa „kultury życia” oraz szerzenia jej w świecie. Bycie katolikiem zakłada większą odpowiedzialność, która jest spójna $\mathrm{z}$ powołaniem chrześcijańskim oraz wezwaniem do rozpoznawania w życiu ludzkim wymiaru nadprzyrodzonego. Katolik powinien być energicznym głosicielem „ewangelii życia"72.

Ojciec św. Franciszek problematykę życia ukazuje w szerszym kontekście społecznym, ekologicznym, a przede wszystkim nadprzyrodzonym - trochę podobnie jak jego poprzednik Benedykt XVI. Papież Franciszek dużo miejsca poświęcił problematyce jakości życia w swojej encyklice Laudato si', która została poświęcona kwestiom ekologicznym. Człowiek powinien żyć w harmonii z naturą, a nie jako bezwzględny eksplorator i grabieżca dóbr przekazanych mu przez Stwórcę. Franciszek podkreślił, że pogorszeniu się jakości życia zwykle towarzyszy upadek społeczny, degradacja środowiska i społeczeństwa (LS 206). Z powodu postępujących negatywnych zjawisk w świecie papież zachęca do przyjęcia nowego stylu życia, który będzie naznaczony szacunkiem do życia ludzkiego i przyrody ${ }^{73}$. Według Franciszka autentyczna ekologia ludzka powinna zawierać wymiar społeczny oraz musi być wrażliwa

${ }^{70}$ Franciszek, Rozważanie przed modlitwa „Anioł Pański” 5 lutego 2017, „L’Osservatore Romano” wyd. pol. 38 (2017)2,: „Dzisiaj we Włoszech obchodzony jest Dzień Obrony Życia, pod hasłem: «Kobiety i mężczyźni w obronie życia śladami św. Teresy z Kalkuty». Jednoczę się z biskupami włoskimi w nadziei na odważną akcję wychowawczą na rzecz życia ludzkiego. Każde życie jest święte! Rozwijajmy kulturę życia jako odpowiedź na logikę odrzucania i spadek demograficzny; bądźmy blisko i módlmy się razem za dzieci, których życie jest zagrożone przez przerwanie ciąży, i za osoby u kresu życia - każde życie jest święte! - aby nikt nie pozostał sam, a miłość żeby broniła sensu życia. Przypomnijmy słowa Matki Teresy: «Życie jest pięknem, podziwiaj je; życie jest życiem, broń go!», zarówno dziecka, które ma się narodzić, jak i osoby, która zbliża się do śmierci: każde życie jest święte!" - http://www.opoka.org.pl/biblioteka/W/WP/ franciszek_i/modlitwy/ap_05022017.html [dostęp: 30.06.2017].

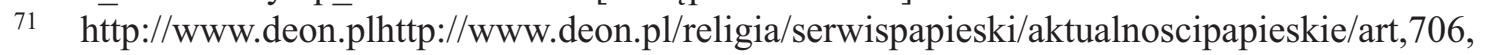
papiezzycialudzkiegotrzebabroniczawsze.html , [dostęp: 30.06.2017].

$72 \mathrm{http} / / /$ www.deon.plhttp://www.deon.pl/religia/serwispapieski/aktualnoscipapieskie/art,867, franciszekdolekarzybronciekulturyzycia.html [dostęp: 30.06.2017].

${ }^{73}$ M. Pisarek, Wyzwania dla współczesnego Kościoła w świetle encykliki Laudato si' papieża Franciszka, „Studia Leopoliensia” 8 (2015), s. 457-467. 
na głos swojej planety połączony z wołaniem ludzi żyjących w nędzy. W swoim orędziu papież upomina się o człowieka, o ochronę jego życia od poczęcia do naturalnej śmierci, o jego wymiar duchowy i kulturę ${ }^{74}$.

Według niego to wiara nadaje ludzkiemu życiu właściwe wymiary, sens i znaczenie, ustala istotną skalę wartości. To ona w istocie kształtuje i dynamizuje życie. To ona dokonuje wewnętrznej przemiany osoby oraz kształtuje wspólnotę Kościoła. Dzięki temu staje się ona szkołą chrześcijańskiego życia moralnego, nakreślonego postawami i zachowaniem człowieka. Tylko taka wiara, pielęgnowana od dzieciństwa w rodzinie, stanowi centrum własnej egzystencji człowieka, a tym samym oddziałuje na życie, wynosząc je na wysoki poziom moralny i tylko taka wiara prowadzi do postawy nadziei ${ }^{75}$.

Podsumowując, należy stwierdzić, że wszyscy ostatni papieże jednoznacznie przypominają i nauczają, że ludzkie życie jest święte i ma niezbywalną godność przez cały czas od poczęcia po jego kres w naturalnej śmierci. Wartość ludzkiego życia zakorzeniona jest w stworzeniu człowieka na obraz i podobieństwo Boże i jest niezależna od jakości życia i sposobu egzystencji jednostki ludzkiej. Wszyscy następcy św. Piotra ukazują życie chrześcijanina w perspektywie nadprzyrodzonej. Przypominają również o licznych zagrożeniach takich, jak: aborcja, manipulacje genetyczne, wojny, eutanazja. Wielkim obrońcą ludzkiego życia oraz promotorem kultury życia był św. Jan Paweł II. Papież Benedykt XVI oraz papież Franciszek w większym stopniu wskazują na społeczny wymiar życia ludzkiego, podkreślając konieczność polepszenia jakości ludzkiej egzystencji. Jest to o tyle ważne, że współczesny świat gubi się, mieszając kategorię bezwzględnej wartości życia ludzkiego z bliżej nieokreśloną kategorią jakości życia ${ }^{76}$. Można zaryzykować stwierdzenie, że Jan Paweł II wyraźnie bronił i promował wartość życia w jego istocie, zaś jego następcy, nie zaprzeczając jego nauczaniu, wskazują na egzystencjalną i społeczną wartość życia.

Kończąc, należy przypomnieć, że św. Papież Jan Paweł II prosił o budzenie sumień i o modlitwę za życie. O tę modlitwę prosił wszystkie chrześcijańskie rodziny, ruchy, stowarzyszenia i wspólnoty (Evangelium vitae 84, $93,100)$. Zachęcał również do przyjęcia postawy kontemplacji, rodzącej się

\footnotetext{
${ }^{74}$ J. Kwiatkowski, Nowa encyklika papieża Franciszka: zaskakująca, niewygodna, inspirujaca, w: http://dziennikparafialny.pl/2015/nowa-encyklika-papieza-ranciszkazaskakujaca-niewygodnainspirujaca/ [dostęp: 14.07.2015].

${ }^{75}$ M. Kluz, Wiara $w$ życiu i postawie moralnej człowieka $w$ świetle encykliki Lumen fidei papieża Franciszka, „Polonia Sacra” 17(2013) 2, s. 128.

${ }^{76}$ T. Biesaga, Wartość życia w ujęciu etyki personalistycznej, „Seminare” 19 (2003), s. 169-175.
} 
z wiary w Boga życia ${ }^{77}$. Modlitwa przybliża człowieka do źródła życia. Pozwala zasmakować jemu istoty życia i odkryć mały rąbek jego istoty. Można powiedzieć, że bez modlitwy człowiek przestaje rozumieć sens życia, przechodzi na stronę cienia i powoli zaczyna sprzyjać kulturze śmierci.

\section{THE VALUE OF HUMAN LIFE IN THE TEACHING OF POPES JOHN PAUL II, BENEDICT XVI AND POPE FRANCIS}

\section{Summary}

The article presents the teachings of Popes John Paul II, Benedict XVI and Francis on the value of human life. St. John Paul II has developed the foundations of the science of the value of life.

All the last popes unequivocally teach that human life is sacred and possesses an inescapable dignity all the time from conception to its end in natural death. The value of human life is rooted in the creation of man in the image and likeness of God, and is independent of the quality of life and the way of human existence. All successors of St. Peter shows the life of a Christian in a supernatural perspective. They also remind us of the many dangers of life such as abortion, genetic manipulation, war, euthanasia. The great defender of human life was St. Pope John Paul II. Pope Benedict XVI and Pope Francis point to the social dimension of human life, emphasizing the need to improve the quality of human existence. It is so important that the modern world is lost by mixing the category of absolute value of human life with the unspecified quality of life category.

Słowa kluczowe: wartość życia; świętość życia; godność życia; Jan Paweł II; Benedykt XVI; Papież Franciszek

Keywords: value of life; sacredness of life; dignity of life; John Paul II; Benedict XVI; Pope Francis

\section{BIBLIOGRAFIA}

Bendedykt XVI, Encyklika Caritas in veritate (CiV), (29 czerwca 2009), http://w2.vatican.va/content/benedict-xvi/pl/encyclicals/documents/hf_ben-xvi_enc_20090629_caritas-in-veritate.html [dostęp: 30.06.2017].

Bendedykt XVI, Encyklika Deus caritas est (DCE), (25 grudnia 2005) https://w2.vatican.va/content/benedict-xvi/pl/encyclicals/documents/hf_ben-xvi_enc_20051225_deus-caritas-est.html [dostęp: 30.06.2017].

${ }^{77}$ Jan Paweł II, Evangelium vitae, nr 83. 
Bendedykt XVI, Encyklika Spe salvi (SS), (30 listopada 2007) http://w2.vatican.va/content/ benedict-xvi/pl/encyclicals/documents/hf_ben-xvi_enc_20071130_spe-salvi.html [dostęp: 30.06.2017].

Benedykt XVI, Człowiek to coś więcej niż kombinacja informacji genetycznych, „L'Osservatore Romano" wyd. pol. 30 (2009) 4, s. 32.

Benedykt XVI, Dlaczego wierzę? Przesłanie pontyfikatu 2005-2013, Kraków 2013.

Benedykt XVI, Gdy człowiek postęuje wbrew sumieniu, rani samego siebie, „L'Osservatore Romano" wyd. pol. 32 (2011) 4, s. 14.

Benedykt XVI, Ludzka i chrześcijańska godność prokreacji, „L'Osservatore Romano” wyd. pol. 33 (2012), nr 4, s. 39.

Benedykt XVI, Orędzie Ojca Świętego Benedykta XVI na Światowy Dzień Pokoju, 1.I.2007, p. 5. http://www.opoka.org.pl/biblioteka/W/WP/benedykt_xvi/przemowienia/pokoj2007_08122006. html [dostęp: 30.06.2017].

Benedykt XVI, Przestanie do uczestników 25. Międzynarodowej Konferencji Papieskiej Rady ds. Stużby Zdrowia i Duszpasterstwa Chorych, „L'Osservatore Romano” wyd. pol. 32 (2011), nr 1, s. 25.

Benedykt XVI, Serce rozumne. Refleksje na temat podstaw prawa, „L'Osservatore Romano” wyd. pol. 32 (2011) 4, s. 39.

Benedykt XVI, Spotkanie z członkami rządu, instytucji państwowych, korpusu dyplomatycznego, zwierzchnikami religijnymi i przedstawicielami świata kultury, 15.IX.2012, „L'Osservatore Romano" wyd. pol. 33 (2012), s. 9-10.

Benedykt XVI, Wiedeń. Spotkanie ze światem polityki, 7.IX.2007, „L'Osservatore Romano” wyd. pol. 28 (2007), s. 10-11.

Benedykt XVI, Życie jest pierwszym dobrem, jakie otrzymujemy od Boga, i podstawa wszystkich innych, „L'Osservatore Romano” wyd. pol. 28 (2007), nr 5, s. 45.

Benedykt XVI, Życie ma wielka wartość, nawet kiedy jego piękno przysłania tajemnica cierpienia. Orędzie Ojca Świętego na XVII Światowy Dzień Chorego, „L'Osservatore Romano” wyd. pol. 30 (2009), nr 3, s. 8.

Biesaga T., Wartość życia w ujęciu etyki personalistycznej, „Seminare” 19(2003), s. 169-175.

Cieślik D., Nienaruszalność życia ludzkiego w nauczaniu Benedykta XVI, „Studia Teologiczno-Historyczne Śląska Opolskiego" (2015) 35, s. 209-220.

Franciszek, Przemówienie do przedstawicieli Włoskiego Stowarzyszenia Lekarzy Katolickich 15.11.2014, „L'Osservatore Romano” wyd. pol. 35 (2014), s. 12.

Franciszek, Rozważanie przed modlitwa „Anioł Pański” 5 lutego 2017, „L'Osservatore Romano” wyd. pol. 38 (2017) $\mathrm{nr} 2$.

Franciszek, Encyklika Laudato si' (LS), (24 maja 2015) https://w2.vatican.va/content/dam/france sco/pdf/encyclicals/documents/papa-francesco_20150524_enciclica-laudato-si_pl.pdf [dostęp: 30.06.2017].

Franciszek, Encyklika Lumen fidei (LF), (29 czerwca 2013) https://opoka.org.pl/biblioteka/W/WP/ franciszek_i/encykliki/lumen_fidei_29062013.html [dostęp: 30.06.2017].

Franciszek, Adhortacja Evangelii gaudium (EG), (24 listopada 2013) https://w2.vatican.va/content/ francesco/pl/apost_exhortations/documents/papa-francesco_esortazione-ap_20131124_evan gelii-gaudium.html [dostęp: 30.06.2017].

Franciszek, Adhortacja Amoris laetitia (AL), (19 marca 2016) https://opoka.org.pl/biblioteka/W/ WP/franciszek_i/adhortacje/amoris_laetitia_19032016.html [dostęp: 30.06.2017].

Grześkowiak A., Wybrane aspekty nauczania Benedykta XVI o rodzinie, w: Człowiek z perspektywy religii, rodziny i szkoły, red. H. Czakowska, M. Kucinski, Bydgoszcz 2013.

Jan Paweł II, Adhortacja Familiaris consortio (FC), (22 listopada 1981) https://opoka.org.pl/ biblioteka/W/WP/jan_pawel_ii/adhortacje/familiaris.html [dostęp: 30.06.2017].

Jan Paweł II, Encyklika Veritatis splendor (VS), (6 sierpnia 1993), „Acta Apostolicae Sedis” 85 (1993), s. 1169. 
Jan Paweł II, Encyklika Evangelium vitae (EV), (25 marca 1995) https://opoka.org.pl/biblioteka/W/ WP/jan_pawel_ii/encykliki/evangelium_1.html [dostęp: 30.06.2017].

Katechizm Kościoła katolickiego, tekst polski, Poznań 1994.

Kluz M., Wiara w życiu i postawie moralnej czlowieka $w$ świetle encykliki Lumen fidei papieża Franciszka, „Polonia Sacra” 17(2013) 2, s. 113-129.

Kongregacja Nauki Wiary, Deklaracja o eutanazji Iura et bona (5 maja 1980), „Acta Apostolicae Sedis" 72(1980), s. 546-551.

Kongregacja Nauki Wiary, Instrukcja Dignitas personae dotycząca niektórych problemów bioetycznych, (12 grudnia 2008), https://opoka.org.pl/biblioteka/W/WR/kongregacje/kdwiary/dignitas personae_12122008.html [dostęp: 30.06.2017].

Kongregacja Nauki Wiary, Instrukcja Donum vitae, II, B, 7, „Acta Apostolicae Sedis” 80 (1988), s. 96.

Kwiatkowski J., Nowa encyklika papieża Franciszka: zaskakująa, niewygodna, inspirująca, w: http://dziennikparafialny.pl/2015/nowa-encyklika-papieza-ranciszkazaskakujaca-niewygodnainspirujaca/ [dostęp: 14.07.2015].

Ozorowski E., Dar życia w porządku stworzenia i zbawienia w świetle „Evangelium vitae”, w: Evangelium vitae - ocaleniem rodziny, red. M. Ozorowski, Częstochowa 1997, s. 61-63.

Paweł VI, Encyklika Humanae vitae (25 lipca 1968), „Acta Apostolicae Sedis” 60 (1968).

Pisarek M., Wyzwania dla współczesnego Kościoła w świetle encykliki Laudato si papieża Francisz$k a$, ,Studia Leopoliensia” 8(2015), s. 457-467.

Pius XII, Przemówienie do uczestników IV Międzynarodowego Kongresu Lekarzy Katolickich (29 września 1949), „Acta Apostolicae Sedis” 41 (1949), s. 560.

Podrez E., Człowiek, byt, wartość, Warszawa 1989.

Ratzinger G., Mój brat papież, tłum. K. Markiewicz, Kraków 2012.

Ratzinger J., Człowiek - reprodukcja czy stworzenie? Teologiczne pytania dotyczące początków życia ludzkiego, „Ethos” 1 (1988) 4, s. 141.

Ratzinger J., Formalne zasady chrześcijaństwa. Szkice do teologii fundamentalnej, Poznań 2009.

Ratzinger J., Nienaruszalność życia ludzkiego w świetle encykliki „Evangelium vitae”, „L'Osservatore Romano" wyd. pol. 16 (1995) nr 5, s. 48.

Ratzinger J., Prawda, wartości, władza. Kiedy społeczeństwo można uznać za pluralistyczne, Kraków 1999.

Ratzinger J., Problem zagrożeń życia ludzkiego, „L’Osservatore Romano” wyd. pol. 12 (1995) 7, s. 4.

Ratzinger J., Wiara i przyszłość, thum. J. Merecki, Kraków 2007.

Ratzinger J., Życie - fundamentalna wartościa i nienaruszalnym prawem czlowieka, „Ethos” $2(1987) 5$, s. 23.

Szymik J., Theologia benedicta, t. 3, Katowice 2015.

MieczYSŁaw Ozorowski, ks. prof. UKSW dr hab. W 1986 roku ukończył Wyższe Seminarium Duchowne w Łomży i otrzymał stopień magistra teologii na Wydziale Teologicznym ATK. W latach 1987-1992 studiował we Fryburgu (Szwajcaria). Był uczniem o. prof. Christopha von Schönborna OP (obecnego kard. Wiednia). W 1992 roku osiągnął stopień doktora. Od 1993 pracował jako adiunkt w Instytucie Studiów nad Rodziną - wcześniej ATK, obecnie UKSW. W 2002 r. habilitował się na Wydziale Teologicznym UKSW w Warszawie. Od 2004 roku jest profesorem nadzwyczajnym Uniwersytetu Kardynała Stefana Wyszyńskiego. Wykłada teologię dogmatyczną w Wyższym Seminarium Duchownym w Łomży. Od 2010 roku jest dziekanem Wydziału Studiów nad Rodziną 
UKSW w Warszawie. Brał udział w wielu konferencjach naukowych. Jest autorem licznych artykułów z zakresu sakramentologii, teologii małżeństwa i rodziny oraz ekoteologii. 